\title{
Certification Status of Family Physicians in the Initial Cohort Entering Maintenance of Certification
}

\author{
James C. Puffer, MD, Andrew W. Bazemore, MD, Robert L. Phillips, MD, MPH, \\ and Diane K. Beebe, MD
}

There existed considerable concern that participation in Maintenance of Certification by board-certified physicians would be less than optimal when it was introduced by the American Board of Medical Specialties in 2000. However, family physicians who entered the first 10-year Maintenance of Certification for Family Physicians cycle in 2003 participated at levels consistent with historical norms. ( $\mathrm{J}$ Am Board Fam Med 2014;27:581-582.)

\section{Keywords: Certification, Health Policy}

When the American Board of Medical Specialties approved and mandated the adoption of Maintenance of Certification (MOC) for all its 24 member boards in 2000, resistance by board-certified physicians to engage in the process suggested that the potential of MOC to improve the quality of care might not be realized. ${ }^{1,2}$ However, after the American Board of Family Medicine (ABFM) introduced MOC for family physicians (MC-FP) in 2003, participation by family physicians was robust, and by 2010 the ABFM became the first American Board of Medical Specialties member board to have transitioned all its more than 80,000 diplomates into the process. ${ }^{3-5}$ In this brief we report on the initial group of family physicians who entered and have now completed their first cycle of MC-FP.

Of the 11,260 diplomates in the first 10-year MC-FP cycle, 8,589 successfully completed the

This article was externally peer reviewed.

Submitted 21 March 2014; revised 9 July 2014; accepted 11 July 2014.

From the American Board of Family Medicine, Lexington, Kentucky (JCP, RLP); the Robert Graham Center for Policy Studies, Washington, D.C. (AWB); and the Department of Family Medicine, University of Mississippi, Jackson (DKB).

Funding: none.

Conflict of interest: JCP is the president and CEO of the ABFM. RLP is the vice president of research and policy for the ABFM.

Corresponding author: James C. Puffer, MD, American Board of Family Medicine, 1648 McGrathiana Parkway, Suite 550, Lexington, KY 40511-1247 (E-mail: jpuffer@ theabfm.org). first 2 stages of MC-FP and earned 3-year extensions of their certificates; of the remaining 2,671 diplomates, 1,335 successfully completed requirements to sit for the MC-FP examination on the 7-year pathway, but only 1,148 maintained certification by passing. ${ }^{4}$ By the end of 2013, 7474 of the diplomates on the 10-year pathway passed the examination. Therefore, 8,622 of the 11,260 diplomates $(76.6 \%)$ who entered MC-FP in 2003 maintained their certification, consistent with historical rates before MC-FP (see Figure 1).

Of the 2638 diplomates who did not maintain certification, 1662 did not complete their MC-FP requirements, 729 met requirements to sit for the examination but failed, 159 indicated that they were retired, and 88 were deceased. Of note, 575 have applied for the 2014 MC-FP examination in an effort to regain certification. The average age of those not maintaining certification was 59.1 years, and 1306 diplomates were older than the age of 60 .

After completion of the first full cycle of MC$\mathrm{FP}$, it seems that family physicians remain invested in this new paradigm at levels consistent with historical recertification rates. Specifically, for any given examination cohort, $75 \%$ to $80 \%$ of those successfully passing the examination will be maintaining their certification before their certificates expire. It seems that the majority of those not maintaining their certification have approached or are approaching retirement age, although an exploration of retirement and other factors leading to the 
Figure 1. Participation in MC-FP by the 2003 cohort.

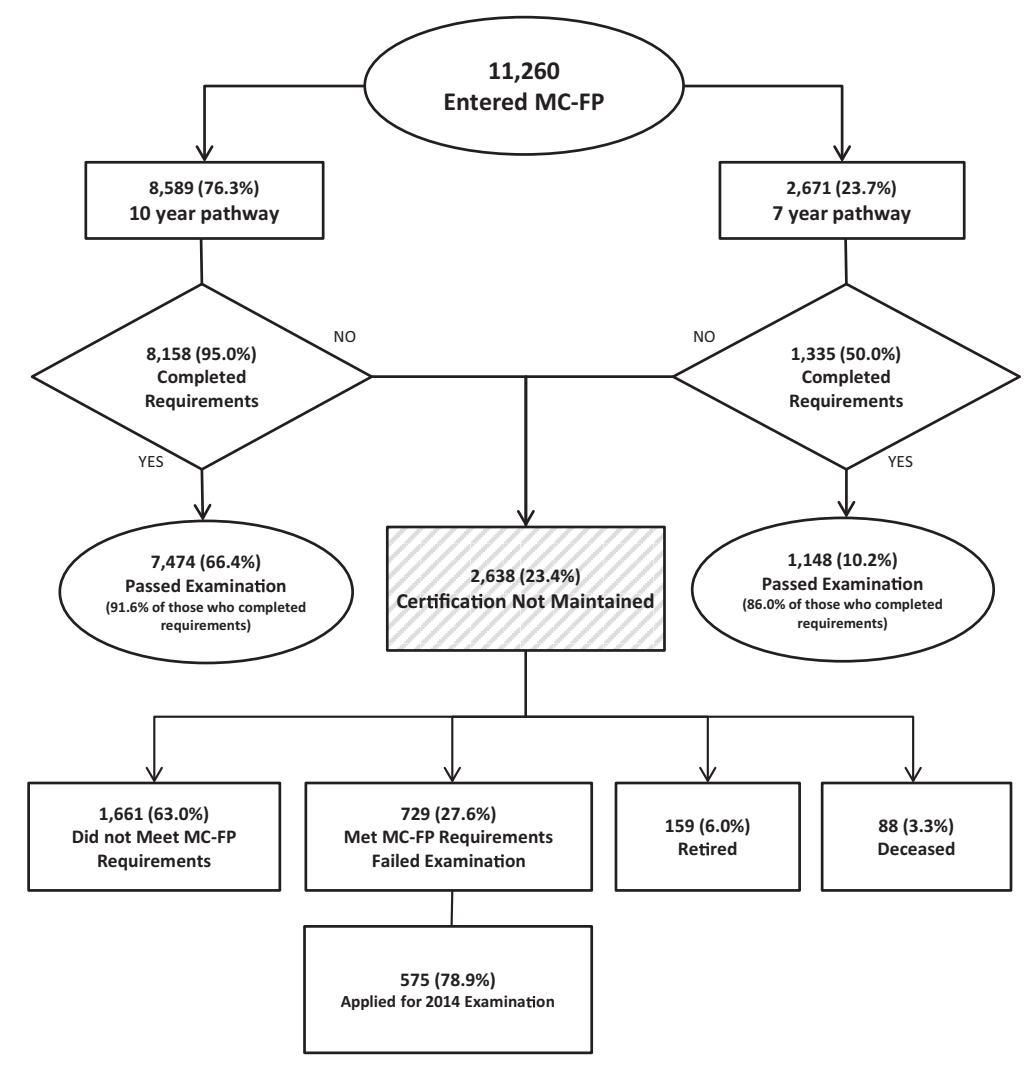

decision not to participate in MC-FP merits further investigation.

\section{References}

1. Levinson W, King TE Jr, Goldman L, Goroll AH, Kessler B. American Board of Internal Medicine maintenance of certification program. N Engl J Med 2010;362:948-52.

2. Drazen JM, Weinstein DF. Considering recertification. N Engl J Med 2010;362:946-7.
3. Xierali IM, Rinaldo JCB, Green LA, et al. Family physician participation in maintenance of certification. Ann Fam Med 2011;9:203-10.

4. Puffer JC, Bazemore AW, Newton W, Makaroff L, Xierali IM, Green LA. Engagement of family physicians seven years into maintenance of certification. J Am Board Fam Med 2011;24:483-4.

5. Puffer JC, Bazemore AW, Jaen CR, Xierali IM, Phillips RL, Jones SM. Engagement of family physicians in maintenance of certification remains high. J Am Board Fam Med 2012;25:761-2. 